TOMASZ SZCZEPAŃSKI

ORCID: 0000-0002-0157-6293

URSZULA WIĘCKIEWICZ

ORCID: 0000-0002-6993-0869

BARBARA KONIOR

ORCID: 0000-0003-2492-7276

PATRYK PUCULEK

ORCID: 0000-0003-3644-6541

DOI: 10.4467/20801335PBW.21.008.13565

\title{
Wpływ dezynfekcji pomieszczeń ozonem na skuteczność ujawniania śladów daktyloskopijnych na powierzchni papieru metodą DFO w dobie pandemii SARS-CoV-2
}

Obserwowany od początku 2020 r. gwałtowny wzrost zachorowań na COVID-19 wywołanych zakażeniem koronawirusem SARS-CoV-2 (ang. Severe acute respiratory syndrome coronavirus 2) oraz ogłoszenie w marcu ubiegłego roku przez WHO stanu pandemii spowodowały zwiększenie zainteresowania technikami dezynfekcji niszczącymi przede wszystkim wirusy. Jedną z takich metod jest ozonowanie. Niebezpieczeństwo zakażenia może wynikać z kontaktu materiału, np. przesyłki pocztowej, z nosicielem wirusa, szczególnie asymptomatycznym. Możliwe jest także intencjonalne skierowanie skażonego listu w celu wywołania zagrożenia. Wymusza to wypracowanie skutecznej metody dezynfekcji, która zapewni względne bezpieczeństwo odbiorcom. Jednocześnie aby umożliwić ewentualną identyfikację nadawcy, w tym m.in. na podstawie śladów daktyloskopijnych, niezwykle istotne jest stosowanie takich technik dezynfekcji, które nie zniszczą śladów kryminalistycznych. Ponadto, z punktu widzenia czynności wykrywczych, jest ważne ustalenie, czy ślady daktyloskopijne pozostawione na podłożu papierowym (np. list, koperta, dokument) poddanym ozonowaniu nie ulegają zniszczeniu.

W czasie pandemii i realnego zagrożenia infekcją wirusem SARS-CoV-2 warto przytoczyć kilka faktów. Koronawirusy, a dokładnie cztery serotypy HCoV (ang. human coronavirus): HCoV-229E, HCoV-OC43, HCoV-NL63, HCoV-UKU1, są od lat 
odpowiedzialne za przeziębienia i infekcje grypopodobne u ludzi ${ }^{1}$. Szacuje się, że powodują 2-10 proc. zimowych lub wczesnowiosennych przeziębień z pojawiającymi się co dwa-cztery lata epidemiami². Będący przyczyną obecnej pandemii SARS-CoV-2 jest siódmym znanym wirusem infekującym człowieka należącym do rodziny Coronaviridae. Pierwszy ludzki koronawirus powodujący zagrażającą życiu infekcję dolnych dróg oddechowych - ostrą niewydolność oddechową, oznaczony jako SARS-CoV, pojawił się w Chinach w 2002 r. $^{3}$ Równie groźny okazał się kolejny koronawirus MERS-CoV (ang. Middle East respiratory syndrome coronavirus), który tym razem pojawił się na Półwyspie Arabskim w 2012 r. Jednak zarówno SARS-CoV, jak i MERS-CoV nie spowodowały pandemii, mimo że przypadki infekcji odnotowano w wielu krajach na różnych kontynentach.

Ludzkie koronawirusy (HCoV) są w stanie zachować infekcyjność w temperaturze pokojowej na różnych powierzchniach nawet do $9 \mathrm{dni}^{4}$. Badania dotyczące obecności koronawirusa SARS-CoV-2 na konkretnych podłożach wskazują na jego większą stabilność na powierzchni plastiku i stali nierdzewnej niż na miedzi i tekturze. Wirus w formie umożliwiającej zakażenie był wykrywany na plastiku do 72 godzin $\mathrm{w}$ temperaturze $21-22^{\circ} \mathrm{C}$, przy wilgotności 40 proc. $\mathrm{RH}^{5}$, przy czym znacząco zmniejszała się jego ilość w czasie. Na tekturze, w podobnych warunkach, wirus zdolny do wywołania infekcji był wykrywany do 24 godzin ${ }^{6}$. Kolejne badania dotyczyły określenia wpływu temperatury na stabilność SARS-CoV-2 na różnych powierzchniach. Należy podkreślić, że $\mathrm{w}$ trakcie tych badań wyeliminowano wpływ promieniowania UV; próbki przechowywano w ciemności, przy stałej wilgotności 50 proc. RH. W temperaturze $20^{\circ} \mathrm{C}$ na szkle, polimerowych i papierowych banknotach, stali nierdzewnej oraz tworzywie sztucznym (winylu) SARS-CoV-2 był wykrywany nawet przez 28 dni od momentu naniesienia. Na bawełnianej tkaninie SARS-CoV-2 nie był wykrywany już po 14 dniach. Wzrost temperatury o $10^{\circ} \mathrm{C}$ skracał czas obecności SARS-CoV-2 na stali nierdzewnej, polimerowych banknotach i szkle do 7 dni, natomiast na winylu i bawełnianej tkaninie do 3 dni. Przy tej temperaturze SARS-CoV-2 na powierzchni papierowych banknotów był wykrywany nawet do 21 dni od momentu naniesienia. Znaczną redukcję obecności wirusa SARS-CoV-2 na badanych powierzchniach notowano przy $40^{\circ} \mathrm{C}$ : na bawełnianej tkaninie nie stwierdzono jego obecności już

1 M.G. Hemida. M.M. Ba Abduallah, The SARS-CoV-2 outbreak from a one health perspective, „One Health" 2020, t. 10, https://doi.org/10.1016/j.onehlt.2020.100127 [dostęp: 16 III 2020].

2 L. Collier, J. Oxford, Wirusologia. Podręcznik dla studentów medycyny, stomatologii i mikrobiologii, M. Łuczak (red.), tłum. M.M. Krajewska, Warszawa 1996, s. 134-135.

3 W. Irving, D. Ala'Aldeen, T. Boswell, Mikrobiologia medyczna, Warszawa 2008, s. 90.

4 G. Kampfi i in., Persistence of coronaviruses on inanimate surfaces and their inactivation with biocidal agents, „Journal of Hospital Infection” 2020, t. 104, s. 246-251.

5 Ang. Relative Humidity - dopuszczalna względna wilgotność otoczenia (przyp. red.).

6 N. van Doremalen i in., Aerosol and Surface Stability of SARS-CoV-2 as Compared with SARSCoV-1, „The New England Journal Medicine” 2020, nr 16, s. 1564-1567, https://www.nejm.org/ doi10.1056/NEJMc2004973 [dostęp: 13 X 2020]. 
po 24 godzinach, a na pozostałych badanych podłożach - po 48 godzinach ${ }^{7}$. Badania przeprowadzone przez kanadyjskich naukowców wykazały obecność wirusa SARS-CoV-2: na plastiku - 21 dni od momentu naniesienia, na stali nierdzewnej - 14 dni od momentu naniesienia, na nitrylowych rękawiczkach - 7 dni od momentu naniesienia, na chemoodpornych rękawiczkach - 4 dni od momentu naniesienia, na maskach filtracyjnych typu N-95 i N-100 - 21 dni od momentu naniesienia, na kombinezonie Tyvek - 14 dni od momentu naniesienia. W przypadku bawełny SARS-CoV-2 nie był wykrywany po 24 godzinach od pozostawienia. Należy nadmienić, że te podłoża przechowywano w temperaturze $20^{\circ} \mathrm{C}$ i wilgotności 40 proc. $\mathrm{RH}^{8}$.

Przytoczone dane dotyczące między innymi tworzyw sztucznych i tektury nie zostały wybrane przypadkowo. Obiektami badań daktyloskopijnych są często paczki oraz różnego rodzaju przesyłki. Paczki są wykonane powszechnie z tektury, miejscami oklejonej taśmą z tworzywa sztucznego. Przesyłki listowe to zazwyczaj papierowa koperta, która zawiera czasem okienko z przezroczystego tworzywa sztucznego. Niezależnie od pandemii wywołanej wirusem SARS-CoV-2 zagrożeniem mogą być także inne niebezpieczne patogeny, szczególnie te powodujące infekcje o wysokiej śmiertelności, jak wąglik, dżuma, ospa, wirus gorączki krwotocznej.

Konieczność dezynfekcji wszystkich dotykanych powierzchni, zwłaszcza w dobie pandemii, potwierdzają badania przeprowadzone w Singapurze. Wykryto RNA koronawirusa SARS-CoV-2 na większości powierzchni w pomieszczeniu, w którym przebywał pacjent $\mathrm{z}$ symptomami choroby COVID-19. Próbki pobierano przed rutynową procedurą dezynfekcji powierzchni przy wykorzystaniu dichlorocyjanouranu sodu w stężeniu 5000 ppm (ang. parts per million, pol. liczba cząstek na milion). Próbki $\mathrm{z}$ powierzchni pobierano także w dwóch innych pomieszczeniach, w których również przebywali pacjenci z objawami tej choroby, jednak zrobiono to po dezynfekcji przeprowadzonej tam dwa razy w ciągu dnia. W tym przypadku nie stwierdzono RNA koronawirusa. Należy jednak podkreślić, że w takich okolicznościach samo wykrycie RNA koronawirusa SARS-CoV-2 nie oznacza obecności cząsteczek wirusa o zdolnościach infekcyjnych ${ }^{9}$.

Ozon $\left(\mathrm{O}_{3}\right)$ jest uważany za efektywny środek dezynfekujący stosowany między innymi do uzdatniania wody. Przewyższa on skutecznością inne środki chemiczne, takie jak chlor, chloramina, dwutlenek chloru. Jako naturalny składnik stratosfery ozon powstaje na wysokości ok. $30 \mathrm{~km}$ w wyniku oddziaływania promieniowania UV na tlen, w niższych warstwach atmosfery może powstawać natomiast na skutek wyładowań

7 S. Riddell $\mathrm{i}$ in., The effect of temperature on persistence of SARS-CoV-2 on common surfaces, „Virology Journal" 2020, nr 17, https://doi.org/10.1186/s12985-020-01418-7 [dostęp: 13 X 2020].

8 S.B. Kasloff i in., Stability of SARS-CoV-2 on critical personal protective equipment, MedRxiv, https:// doi.org/10.1101/2020.06.11.20128884 [dostęp: 13 X 2020].

9 Sean Wei Xiang Ong i in., Air, Surface Environmental, and Personal Protective Equipment Contamination by Severe Acute Respiratory Syndrome Coronavirus 2 (SARS-CoV-2) from a Symptomatic Patient, „Journal of the American Medical Association” 2020, nr 16, s. 1610-1612. 
atmosferycznych ${ }^{10}$. W troposferze ozon powstaje $\mathrm{w}$ dużej mierze $\mathrm{z}$ gazów pochodzących ze źródeł antropogenicznych, w wyniku reakcji fotochemicznych w obecności światła słonecznego i zanieczyszczeń prekursorowych ${ }^{11}$.

Cząsteczka ozonu składa się z trzech atomów tlenu i jest drugą odmianą alotropową tlenu występującą w biosferze. Czysty gaz ma ostry, gryzący zapach, jest łatwopalny i toksyczny. Otrzymuje się go w wyniku cichych wyładowań elektrycznych, które powodują częściową przemianę tlenu w ozon. W ten sposób można uzyskać stężenie nieprzekraczające 10 proc. Większe stężenia ozonu lub czysty ozon uzyskuje się podczas procesu frakcyjnej kondensacji mieszaniny tlenu i ozonu. Ozon w krótkim czasie przechodzi z powrotem w tlen. Czysty ciekły $\mathrm{O}_{3}$ może mieć właściwości wybuchowe, gdyż reakcja jego rozkładu na tlen, katalizowana przez wiele materiałów, jest silnie egzotermiczna. Jest on silnym utleniaczem, reaguje szybciej niż tlen, a zdolnością utleniania ustępuje tylko fluorowi ${ }^{12}$. Ozon jest bardzo reaktywny $\mathrm{z}$ substancjami organicznymi. W trakcie ozonolizy rozkłada się do niestałego ozonku, degradując następnie do karbonylu i jonu obojnaczego, który reaguje m.in. z wolnymi aminokwasami, grupami sulfohydrolowymi, aldehydami, alkoholami, estrami lub wodą, tworząc nadtlenki. Ozon szczególnie szybko reaguje z nienasyconymi kwasami tłuszczowymi, niszcząc wiązania podwójne i tworząc wiązania peroksydowe ${ }^{13}$.

Ze względu na swoje właściwości utleniające ozon stał się jednym ze sposobów skutecznego eliminowania zagrożenia przenoszenia infekcji za pośrednictwem dotykanych powierzchni. Jednak, jak podaje Narodowy Instytut Zdrowia Publicznego Państwowy Zakład Higieny, istnieją pewne niejasności dotyczące skuteczności wirusobójczego działania ozonu w stanie gazowym, które jest słabiej udokumentowane i zależy w dużej mierze od stężenia ozonu w powietrzu pomieszczenia oraz od czasu jego działania ${ }^{14}$. Podobną opinię zawiera komunikat Centralnego Instytutu Ochrony Pracy - Państwowego Instytutu Badawczego ${ }^{15}$. Badania przeprowadzone przez Jamesa B. Hudsona i in. (2009 r.) wykazały, że maksymalne właściwości wirusobójcze ozonu występują po osiągnięciu szczytowego stężenia gazowego ozonu o wartości 20-25 ppm

10 J. Szaflik, Ozon - wróg czy przyjaciel?, „Biuletyn Informacyjny Stowarzyszenia nRetina AMD Polska", http://idn.org.pl/psrp/ozon.html [dostęp: 20 VII 2020].

11 M. Amann i in., Health risks of ozone from long-range transboundary air pollution, WHO 2008, s. 21, https://www.euro.who.int/_data/assets/pdf_file/0005/78647/E91843.pdf [dostęp: 5 VIII 2020].

12 J.D. Lee, Zwięzła chemia nieorganiczna, Warszawa 1997, s. 241.

13 J. Szaflik, Ozon - wróg czy przyjaciel?...

14 Opinia NIZP-PZH z dn. 2.04.2020 r. dot. dezynfekcji pomieszczeń biurowych poprzez ozonowanie $i$ skuteczności powyższej metody w zwalczaniu SARS-CoV-2 oraz kwestii zwiazanych $z$ bezpieczeństwem jej stosowania, http://wsse.waw.pl/aktualnosci-i-komunikaty/komunikaty/opinia-nizp-pzh-z-dn-2-04-2020-r-dot-dezynfekcji-pomieszczen-biurowych-poprzez-ozonowanie-i-skutecznosci-powyzszej-metody-w-zwal [dostęp: 5 VIII 2020].

15 Komunikat nr 4. Ozonowanie jako metoda przeciwdziałająca skażeniu wirusem SARS-CoV-2, 27 III 2020 r., Centralny Instytut Ochrony Pracy - Państwowy Instytut Badawczy, https://www.ciop.pl/ CIOPPortalWAR/file/89653/2020033104228\&Komunikat-4-Stanowisko-NC-ozonowanie.pdf [dostęp: 5 VIII 2020]. 
(39-49 mg/m³) i wymagają krótkiego okresu wysokiej wilgotności (powyżej 90 proc. $\mathrm{RH})$. Eksperyment przeprowadzano w pomieszczeniu laboratoryjnym o kubaturze $65 \mathrm{~m}^{3}$, wykorzystano trzy generatory rozmieszczone w różnych miejscach, które doprowadzały stężenie ozonu do wartości $25 \mathrm{ppm}$ w ciągu 15 minut i utrzymywały takie stężenie przez 10 minut, po czym gwałtownie zwiększano wilgotność do ponad 95 proc. $\mathrm{RH}$. Badania obejmowały przedstawicieli różnych rodzin wirusów, a uzyskane rezultaty wskazywały stopień inaktywacji przekraczający wartość $3 \log _{10}(99,9 \text { proc. })^{16}$.

Z punktu widzenia badań daktyloskopijnych istotny jest wpływ ozonu na najważniejsze komponenty substancji potowo-tłuszczowej: aminokwasy i tłuszcze. Ozon jako jeden z najsilniejszych znanych utleniaczy reaguje ze związkami organicznymi, doprowadzając do ich utlenienia. Reakcji ulegają tłuszcze występujące na zewnętrznych powierzchniach skóry człowieka, tj. estry woskowe (reaguje 22 proc.), triacyloglicerole (reaguje 25 proc.), di- i monoacyloglicerole (reaguje 10 proc.) oraz nienasycone kwasy tłuszczowe (reaguje 25 proc.). W przybliżeniu w połowie $\mathrm{z}$ tych substancji są obecne nienasycone wiązania węgiel-węgiel, które łatwo wchodzą $\mathrm{w}$ interakcje $\mathrm{z}$ ozonem. Spośród wszystkich nienasyconych związków występujących na powierzchni warstwy rogowej naskórka najbardziej reaktywny jest skwalen. Końcowymi produktami peroksydacji (utleniania - przyp red.) lipidów są aldehydy, węglowodory oraz związki resztkowe, głównie dialdehyd malonowy. Ozon równie dobrze reaguje $\mathrm{z}$ aminokwasami, szczególnie z aminokwasami zawierającymi grupę tiolową ${ }^{17}$.

\section{Materiały i metody}

W Pracowni Badań Daktyloskopijnych Biura Badań Kryminalistycznych Agencji Bezpieczeństwa Wewnętrznego (dalej: Pracownia Badań Daktyloskopijnych BBK ABW) przeprowadzono badania w celu określenia wpływu ozonu wykorzystywanego do dezynfekcji pomieszczeń na skuteczność ujawniania śladów linii papilarnych na podłożach papierowych metodą DFO. W eksperymencie wykorzystano podłoża w postaci arkuszy papieru kserograficznego, na których pozostawiano ślady linii papilarnych naniesione naturalną substancją potową i potowo-tłuszczową oraz sztuczną substancją śladotwórczą pochodzącą ze specjalistycznych poduszek daktyloskopijnych nasączonych aminokwasami i tłuszczami (rys. 1).

${ }_{16}$ J.B. Hudson, M. Sharma, S. Vimalanathan, Development of Practical Method of Using Ozone Gas as a Virus Decontaminating Agent, „Ozone: Science \& Engineering” 2009, t. 31, s. 216-223.

17 A. Wisthaler, Ch.J. Weschler, Reaction of ozone with human skin lipids: Sources of carbonyls, dicarbonyls and hydroxycarbonyls in indoor air, „Proceedings of the National Academy Sciences” 2010, nr 15, s. 6568-6575; J. Szaflik, Ozon - wróg czy przyjaciel?...; H. Zieliński, Ozon - jego znaczenie i toksyczność, „Medycyna Weterynaryjna” 1997, nr 6, s. 325. 


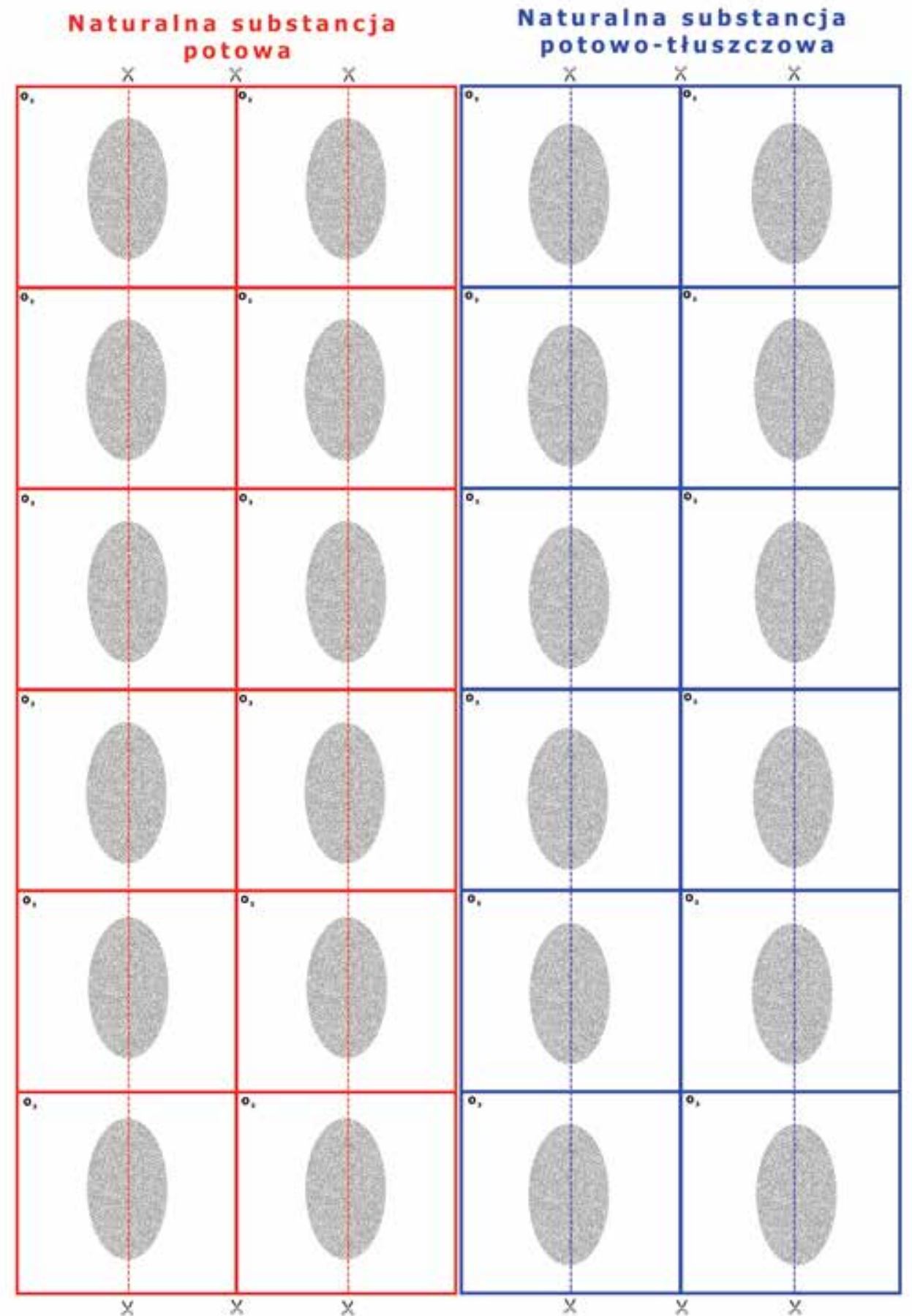

Rys. 1. Przykładowy arkusz, na który nanoszono ślady linii papilarnych ${ }^{18}$.

18 Wszystkie materiały ikonograficzne zostały opracowane przez autorów (przyp. red.). 
Naturalną substancję potową na skórze palców uzyskiwano po kilkunastominutowym noszeniu jednorazowych rękawiczek, a naturalną substancję potowo-tłuszczową pozyskano dzieki potarciu opuszkami palców czoła, którego skóra jest pokryta naturalną wydzieliną w formie emulsji potowo-tłuszczowej.

Badaniami objęto opisane wcześniej ślady linii papilarnych i podłoże, na którym się znajdowały. Podzielono je na trzy grupy (oznaczone literami A, B, C) w zależności od czasu, jaki upływał od momentu pozostawienia śladów do ich ujawnienia (rys. 2).

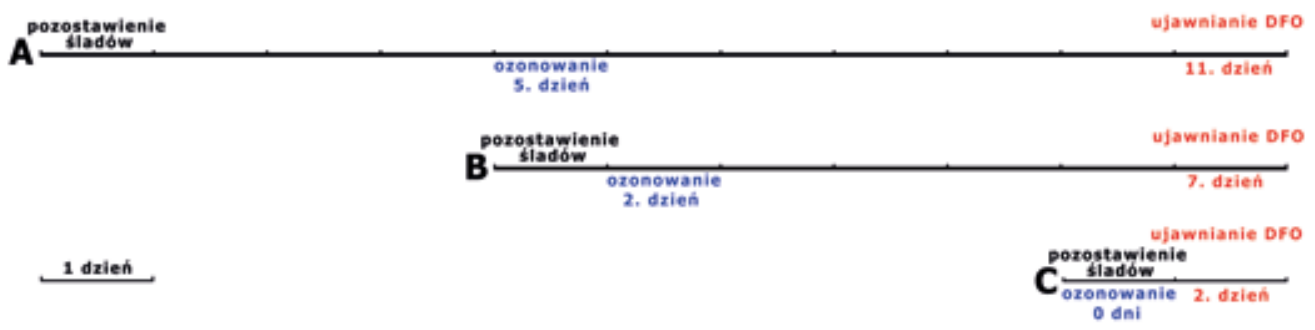

Rys. 2. Schemat przeprowadzenia eksperymentu w trzech przedziałach czasowych (grupa A 11 dni, grupa B - 7 dni, grupa C - 2 dni).

W poszczególnych grupach pozostawiono określoną liczbę śladów:

- grupa A (ślady 11-dniowe) - cztery osoby pozostawiły po 24 ślady linii papilarnych, naniesione czterema rodzajami substancji śladotwórczej,

- grupa B (ślady 7-dniowe) - trzy osoby pozostawily po 12 śladów linii papilarnych, naniesione czterema rodzajami substancji śladotwórczej,

- grupa C (ślady 2-dniowe) - trzy osoby pozostawiły po 24 ślady linii papilarnych, naniesione czterema rodzajami substancji śladotwórczej.

W sumie badania obejmowały 816 śladów linii papilarnych.

Przygotowane podłoża rozcięto $\mathrm{w}$ miejscach pozostawienia śladów linii papilarnych w taki sposób, że każdy ślad podzielono na dwie części: pierwszą umieszczono w pomieszczeniu, które poddano ozonowaniu, drugą określono jako referencyjną i nie poddano jej takiej procedurze (zob. rys. 1). Ozonowanie przeprowadzono w pomieszczeniach o kubaturze ok. $20 \mathrm{~m}^{3}$. W tym celu wykorzystano generator ozonu Airclean7G firmy Ulsonix, który pracując przez jedną godzinę, wytworzył, zgodnie z danymi odczytanymi z czujnika umieszczonego $\mathrm{w}$ pobliżu próbek, maksymalne stężenie $10 \mathrm{ppm}$. Następnie próbki pozostawały w pomieszczeniach przez kolejne dwie godziny, w których dochodziło do rozkładu ozonu i stopniowego spadku jego stężenia. Po tym czasie pomieszczenia były dokładnie wietrzone. W dalszej kolejności podzielone arkusze poddawano procedurze ujawniania śladów linii papilarnych metodą DFO, zgodnie z metodyką przyjętą w Pracowni Badań Daktyloskopijnych BBK ABW ${ }^{19}$. W metodzie DFO jest wykorzystywany odczynnik reagujący $\mathrm{z}$ aminokwasami obecnymi

19 H.L. Bandey, i in., Fingermark Visualisation Manual, (b.m.w.) 2014, s. 5. DFO.1-13. 
w substancji śladotwórczej. Produkt reakcji wykazuje fluorescencję przy maksimum wzbudzenia (długość fali $560 \mathrm{~nm}$ ) i maksimum emisji $(575 \mathrm{~nm})^{20}$. W badaniach wykorzystano metodę DFO także do ujawniania śladów naniesionych sztuczną substancją tłuszczową, zakładając, że będzie ona również skuteczna, ale w mniejszym zakresie. Takie założenie wynika $z$ istnienia dużego prawdopodobieństwa kontaminacji (skażenia - przyp. red.) poduszki tłuszczowej aminokwasami, która zachodzi w trakcie wielokrotnego i powtarzającego się kontaktu palców pokrytych naturalną warstwą substancji potowej stale tworzącą się na skórze ze wspomnianą poduszką.

Po ujawnieniu śladów rozcięte arkusze zestawiano ze sobą i porównywano m.in. ich czytelność, rozmycie linii, poziom fluorescencji. Należy podkreślić, że ocena śladów nie obejmowała określenia liczby minucji ${ }^{21}$, a co za tym idzie - przydatności do identyfikacji poszczególnych połówek. Celem tego porównania było znalezienie właściwości i cech badanych obiektów wspólnych dla nich lub je różniących, w tym przypadku rozdzielonych śladów linii papilarnych ${ }^{22}$. Zestawienie nie obejmowało cech i właściwości wynikających z morfologii linii papilarnych. Na tej podstawie wywnioskowano o negatywnym lub obojętnym wpływie ozonowania pomieszczenia na próbki poddane badaniom. W badaniach nie zakładano możliwości pozytywnego wpływu ozonowania na proces ujawniania śladów linii papilarnych. Rozdzielonym połówkom przypisywano jedną z dwóch wartości: 0 (ślad linii papilarnych słabej jakości) albo 1 (ślad linii papilarnych dobrej jakości). Przypisywanie jednej z tych wartości i porównywanie podzielonych wcześniej śladów zależało od osoby dokonującej oceny i dlatego charakteryzowało się dużym subiektywizmem. Aby zwiększyć obiektywność otrzymanych wyników badań, wszystkie ślady porównywały niezależnie od siebie cztery osoby. Na koniec wyniki zestawiono i przy użyciu programu Microsoft Excel obliczono średnią arytmetyczną uzyskanych ocen. W przypadku gdy obie połowy śladu oceniono jako słabej jakości, zestawiony cały ślad otrzymywał ocenę $0-0$, a gdy dwie połowy śladu oceniono jako dobrej jakości, zestawiony cały ślad otrzymywał ocenę 1-1. Jeżeli stwierdzono, że połowa śladu poddana ozonowaniu otrzymała ocenę „słaba jakość”, a połowa referencyjna otrzymała ocenę „dobra jakość, zestawiony cały ślad otrzymywał ocenę 0-1. W sytuacji odwrotnej zestawiony cały ślad otrzymywał ocenę 1-0. Wyniki badań wszystkich porównywanych śladów zsumowano i zestawiono w formie wykresów (wykresy 1-8).

20 Ch. Champod, Ch. Lennard, P. Margot, M. Stoilovic, Fingerprint and Other Ridge Skin Impressions, Boca Raton-London-New York-Washington 2016, s. 201.

${ }^{21}$ Charakterystyczne elementy budowy linii papilarnych tworzące różne układy linii ciągłych, ich początków i zakończeń oraz odcinków i kropek. Za: J. Moszczyński, Daktyloskopia. Zarys teorii i praktyki, Warszawa 1997, s. 22.

22 J. Apanowicz, Metodologiczne uwarunkowania pracy naukowej. Prace doktorskie. Prace habilitacyjne, Warszawa 2005, s. 30. 


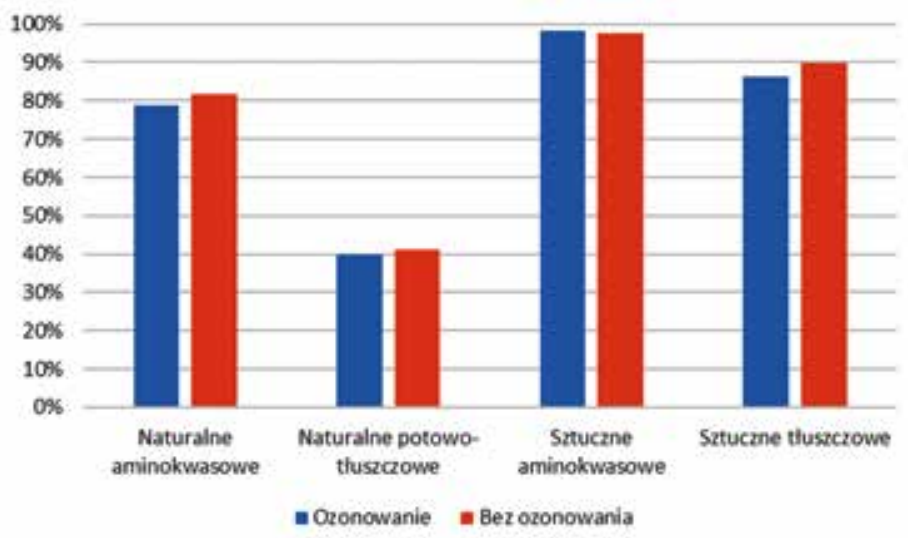

Wykres 1. Wynik porównania jakości 2-dniowych śladów linii papilarnych (grupa C) poddanych ozonowaniu $\mathrm{w}$ dniu pozostawienia $\mathrm{z}$ niepoddanymi ozonowaniu, wyrażony $\mathrm{w}$ procentach.

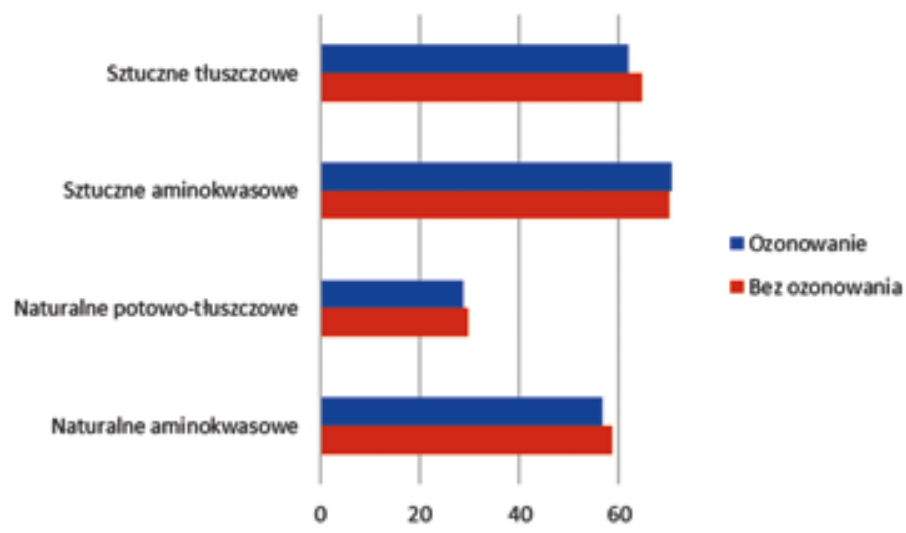

Wykres 2. Wynik porównania jakości 2-dniowych śladów linii papilarnych (grupa C) poddanych ozonowaniu $\mathrm{w}$ dniu pozostawienia $\mathrm{z}$ niepoddanymi ozonowaniu, wyrażony $\mathrm{w}$ liczbach. 


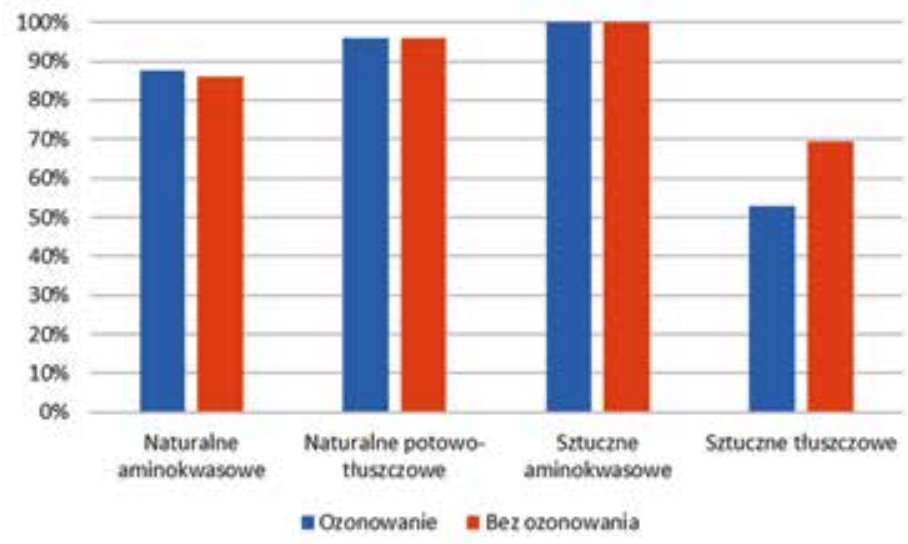

Wykres 3. Wynik porównania jakości 7-dniowych śladów linii papilarnych (grupa B) poddanych ozonowaniu po jednym dniu od pozostawienia $\mathrm{z}$ niepoddanymi ozonowaniu, wyrażony w procentach.

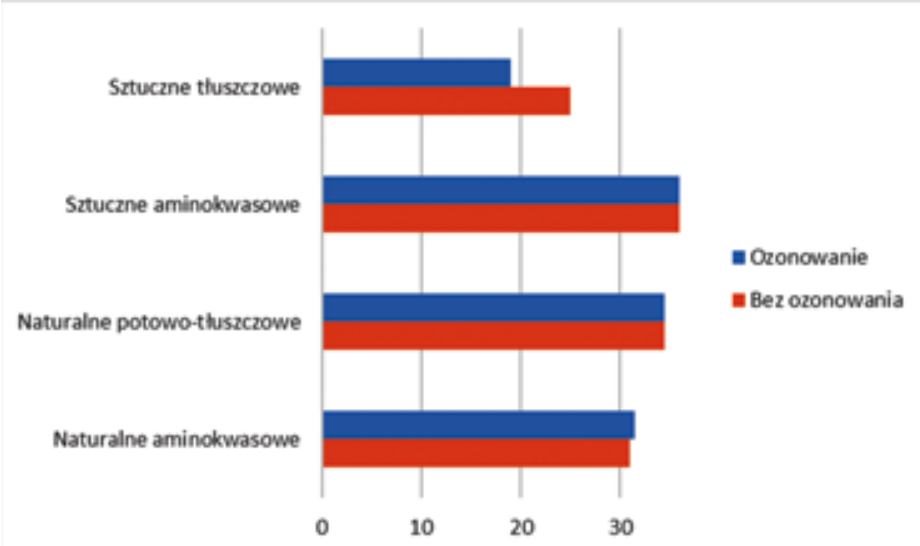

Wykres 4. Wynik porównania jakości 7-dniowych śladów linii papilarnych (grupa B) poddanych ozonowaniu po jednym dniu od pozostawienia $\mathrm{z}$ niepoddanymi ozonowaniu, wyrażony w liczbach. 


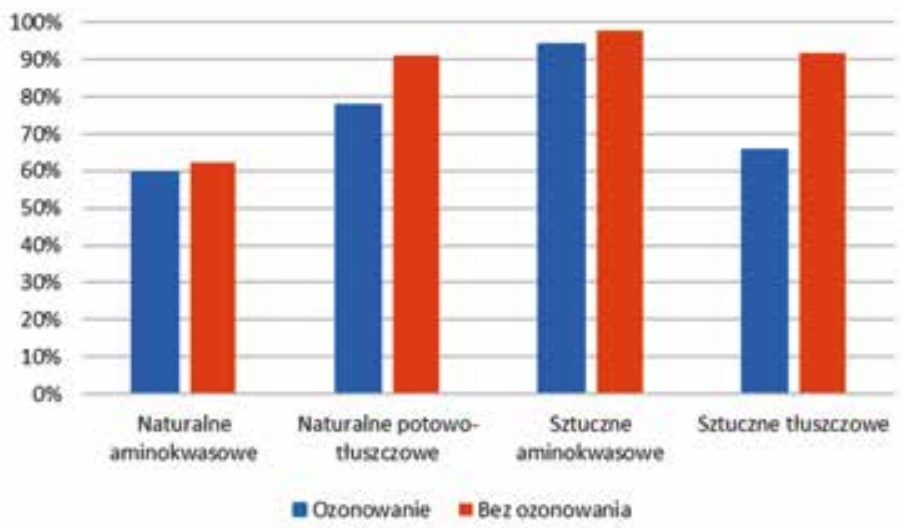

Wykres 5. Wynik porównania jakości 11-dniowych śladów linii papilarnych (grupa A) poddanych ozonowaniu po piątym dniu od pozostawienia $\mathrm{z}$ niepoddanymi ozonowaniu, wyrażony w procentach.

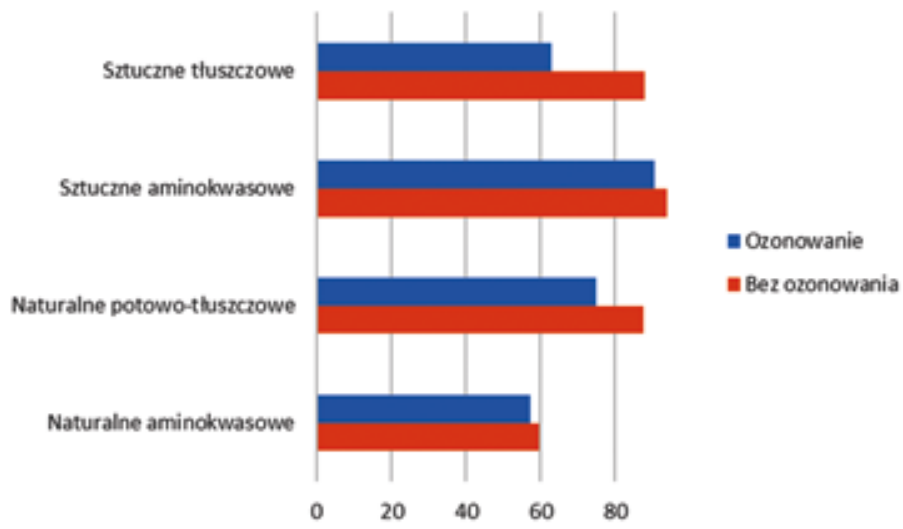

Wykres 6. Wynik porównania jakości 11-dniowych śladów linii papilarnych (grupa A) poddanych ozonowaniu po piątym dniu od pozostawienia $\mathrm{z}$ niepoddanymi ozonowaniu, wyrażony w liczbach. 


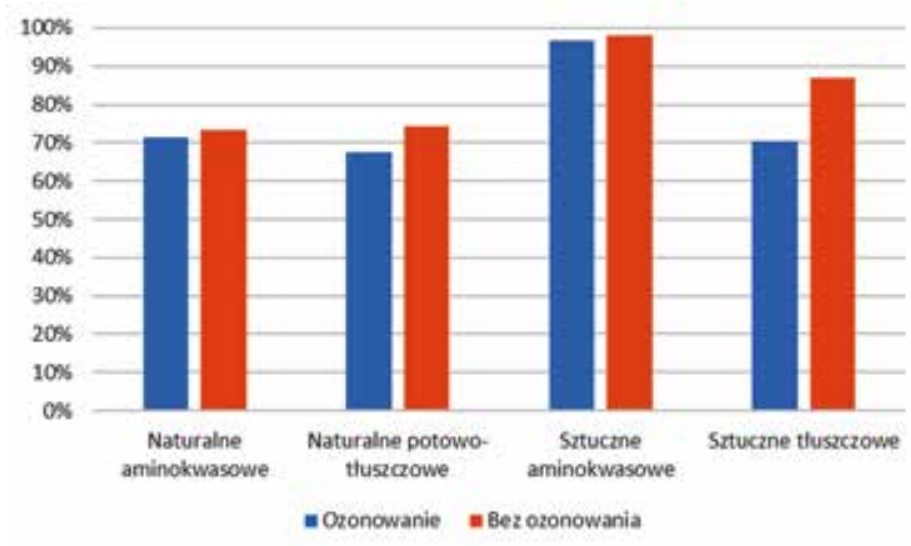

Wykres 7. Suma wyników porównania jakości 816 śladów linii papilarnych poddanych ozonowaniu $\mathrm{z}$ niepoddanymi ozonowaniu, wyrażony w procentach.

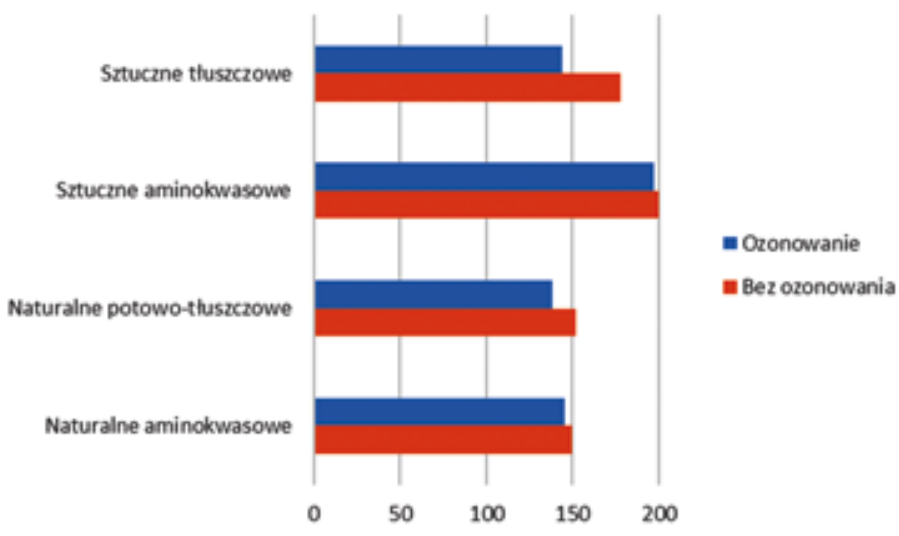

Wykres 8. Suma wyników porównania jakości 816 śladów linii papilarnych poddanych ozonowaniu z niepoddanymi ozonowaniu, wyrażony w liczbach.

W celu określenia wpływu gazowego ozonu na aminokwasy w badaniach wykorzystano także materiał wzorcowy w postaci gotowych do użycia pasków testowych z podłoża papierowego przypominającego bibułę filtracyjną, na którym były cztery pola reakcyjne o zmniejszającym się wykładniczo stężeniu aminokwasów ${ }^{23}$. Paski podzielono na dwie grupy, z których jedną poddano ozonowaniu. Następnie paski

${ }^{23}$ T. Szczepański, U. Więckiewicz, K. Klemczak, Paski testowe do sprawdzania reaktywności metod wizualizacji śladów daktyloskopijnych na podłożach chłonnych z aminokwasami, „Problemy Kryminalistyki” 2015, nr 288, s. 50-53. 
poddano działaniu DFO i porównano efekty wizualizacji przez zestawienie pasków (zdjęcie poniżej).
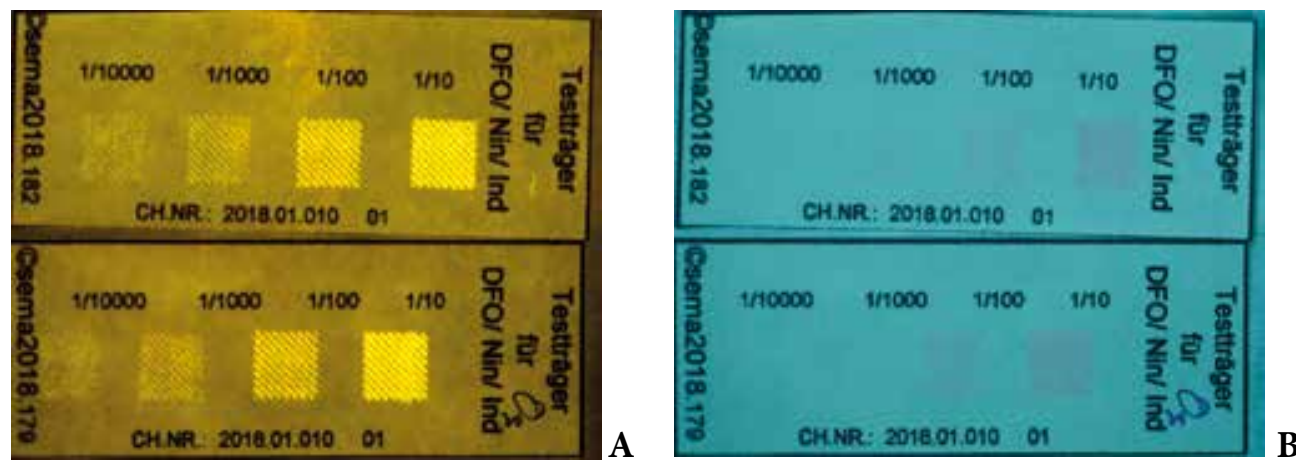

Zdjęcie. Papierowe paski testowe firmy SEMA nasączone aminokwasami o zmniejszającym się wykładniczo stężeniu (paski poddane ozonowaniu oznaczono niebieskim długopisem bezpośrednio na pasku symbolem $\mathrm{O}_{3}$ ), widok we fluorescencji: wzbudzenie - światło niebieskozielone, filtr pomarańczowy (A), widok w białym świetle (B).

\section{Wyniki i dyskusja}

Po przeanalizowaniu otrzymanych wyników w poszczególnych grupach stwierdzono pogorszenie jakości próbek poddanych ozonowaniu w przypadku śladów linii papilarnych naniesionych sztuczną substancją tłuszczową: 7-dniowych o 16 punktów procentowych i 11-dniowych o 26 punktów procentowych oraz naturalną substancją potowo-tłuszczową w przypadku śladów 11-dniowych (o 13 punktów procentowych). Jakość połówek 7-dniowych śladów naniesionych naturalną substancją potowo-tłuszczową nie różniła się. Natomiast w przypadku substancji śladotwórczej zawierającej głównie aminokwasy stwierdzono, że różnice jakości śladów we wszystkich badanych okresach nie przekraczały 4 punktów procentowych (wykresy 1-6).

Po podsumowaniu wszystkich otrzymanych danych stwierdzono pogorszenie jakości ujawnionych śladów - w przypadku śladów linii papilarnych naniesionych sztuczną substancją tłuszczową o 16 punktów procentowych, a naturalną substancją potowo-tłuszczową o 6 punktów procentowych. W przypadku substancji śladotwórczej zawierającej głównie aminokwasy pogorszenie jakości śladów poddanych ozonowaniu nie przekraczało 2 punktów procentowych (wykresy 7 i 8).

Nie ma możliwości ustalenia, czy stwierdzone różnice w jakości śladów naniesionych substancją śladotwórczą zawierającą większą ilość tłuszczowych składników mogły powstać na skutek m.in. utleniania składników pod wpływem ozonowania, co mogło spowodować reakcję aminokwasów z odczynnikiem DFO, czy też te różnice mogą być wynikiem przeprowadzonej procedury ujawniania. Badania obejmowały dużą liczbę próbek, a technika zastosowania metody DFO (zanurzeniowa) i wynikające z niej 
stałe odparowywanie $\mathrm{z}$ roztworu roboczego rozpuszczalnika HFE7100 mogły spowodować zmiany jego stężenia. To zjawisko mogło lekko rozmywać ślady i pogorszyć ich jakość przez częściowe rozpuszczenie emulsji śladotwórczej, która zawiera składniki tłuszczowe. Badania materiału referencyjnego w postaci pasków testowych nasączonych aminokwasami również nie potwierdziły negatywnego wpływu gazowego ozonu na reakcję aminokwasy-DFO, co jest widoczne na zamieszczonym zdjęciu.

Wyniki przeprowadzonej analizy porównawczej zsumowanych danych oraz charakterystyka DFO reagującego z aminokwasami obecnymi w substancji śladotwórczej wskazują, że ozonowanie pomieszczeń przy wykorzystaniu typowego generatora ozonu zapewniającego stężenie nieprzekraczające $10 \mathrm{ppm}$ nie wpływa istotnie na możliwość ujawnienia śladów linii pozostawionych na papierze kserograficznym. Należy podkreślić, że wykonane badania dotyczą stężeń gazowego ozonu nieprzekraczających w pomieszczeniach wartości $10 \mathrm{ppm}$, a zalecana dezynfekcja o udokumentowanym działaniu wirusobójczym powinna zostać przeprowadzona przy urzyciu ozonu w stężeniu przekraczającym 20 ppm, przy znacznie podwyższonej wilgotności.

W przyszłości warto podjąć badania w celu ustalenia, w jakim stopniu stężenia gazowego ozonu przekraczające wartość 10 ppm mogą wpływać na ślady daktyloskopijne i warunkować możliwość ich skutecznego ujawniania.

\section{Podsumowanie}

Dane dotyczące skuteczności dezynfekcji wirusobójczej ozonem w stanie gazowym nie są obszerne, a odnalezione informacje wskazują, że wymagane do inaktywacji wirusów stężenie zapewniające względne bezpieczeństwo jest określane na ok. 25 ppm, przy czym konieczne jest szybkie uzyskanie wilgotności do ponad 90 proc. RH. Przeprowadzone badania $\mathrm{z}$ wykorzystaniem niższych stężeń gazowego ozonu, o wartości nieprzekraczającej $10 \mathrm{ppm}$ bez podwyższania wilgotności potwierdziły, że ślady linii papilarnych pozostawione na papierze kserograficznym umieszczonym $\mathrm{w}$ pomieszczeniu, w którym panują takie warunki, nie ulegają zniszczeniu i z powodzeniem mogą być ujawnione metodą DFO. Należy podkreślić, że potwierdzono skuteczność ujawniania śladów metodą DFO standardowo stosowaną na podłożach chłonnych (m.in. papier), ukierunkowaną wyłącznie na aminokwasy zawarte w substancji śladotwórczej, $\mathrm{w}$ tym obecne $\mathrm{w}$ emulsji tworzącej ślady potowo-tłuszczowe. Badania nie obejmowały metod ujawniania śladów linii papilarnych reagujących z substancją zawierającą składniki tłuszczowe.

Autorzy dziękuja dr Magdalenie Białas, ekspertowi z zakresu badań pisma, za cenne uwagi przy opracowaniu publikacji oraz ekspertom $z$ zakresu badań chemicznych Biura Badań Kryminalistycznych Agencji Bezpieczeństwa Wewnętrznego za pomoc w przeprowadzeniu procesu ozonowania próbek. 


\section{Bibliografia}

Apanowicz J., Metodologiczne uwarunkowania pracy naukowej. Prace doktorskie. Prace habilitacyjne, Warszawa 2005, Difin.

Bandey H.L. i in., Fingermark Visualisation Manual, 2014, Home Office Centre for Applied Science and Technology (CAST).

Champod Ch., Lennard Ch., Margot P., Stoilovic M., Fingerprint and Other Ridge Skin Impressions, Boca Raton-London-New York-Washington 2016, CRC Press.

Collier L., Oxford J., Wirusologia. Podręcznik dla studentów medycyny, stomatologii i mikrobiologii, M. Łuczak (red.), tłum. M.M. Krajewska, Warszawa 1996, Wydawnictwo Lekarskie PZWL.

Hudson J.B., Sharma M., Vimalanathan S., Development of Practical Method of Using Ozone Gas as a Virus Decontaminating Agent, „Ozone: Science \& Engineering” 2009, t. 31, s. 216-223.

Irving W., Ala'Aldeen D., Boswell T., Mikrobiologia medyczna, Warszawa 2008, PWN.

Kampf G., Todt D., Pfaender S., Steinmann E., Persistence of coronaviruses on inanimate surfaces and their inactivation with biocidal agents, „Journal of Hospital Infection” 2020, nr 3, s. 246-251.

Lee J.D., Zwięzła chemia nieorganiczna, Warszawa 1997, PWN.

Moszczyński J., Daktyloskopia. Zarys teorii i praktyki, Warszawa 1997, CLK KGP.

Sean Wei Xiang Ong i in., Air, Surface Environmental, and Personal Protective Equipment Contamination by Severe Acute Respiratory Syndrome Coronavirus 2 (SARS-CoV-2) from a Symptomatic Patient, „JAMA” 2020, nr 16, s. 1610-1612.

Szczepański T., Więckiewicz U., Klemczak K., Paski testowe do sprawdzania reaktywności metod wizualizacji śladów daktyloskopijnych na podłożach chłonnych $z$ aminokwasami, „Problemy Kryminalistyki” 2015, nr 288, s. 50-53.

Wisthaler A., Weschler Ch.J., Reaction of ozone with human skin lipids: Sources of carbonyls, dicarbonyls and hydroxycarbonyls in indoor air, "Proceedings of the National Academy Sciences" 2010, nr 15, s. 6568-6575.

Zieliński H., Ozon - jego znaczenie i toksyczność, „Medycyna Weterynaryjna” 1997, nr 6, s. 325. 


\title{
Źródła internetowe
}

Amann M. i in., Health risks of ozone from long-range transboundary air pollution, WHO 2008, https://www.euro.who.int/_data/assets/pdf_file/0005/78647/E91843.pdf [dostęp: 5 VIII 2020].

N. van Doremalen i in., Aerosol and Surface Stability of SARS-CoV-2 as Compared with SARS-CoV-1, „The New England Journal Medicine” 2020, nr 382 (16), s. 1564-1567, https://www.nejm.org/ doi/full/10.1056/nejmc2004973 [dostęp: 13 X 2020].

Hemida M.G., Ba Abduallah M.M., The SARS-CoV-2 outbreak from a one health perspective, „One Health” 2020, t. 10, https://doi.org/10.1016/j.onehlt.2020.100127 [dostęp: 16 III 2020].

Kasloff S.B., i in., Stability of SARS-CoV-2 on critical personal protective equipment, MedRxiv, https://doi.org/10.1101/2020.06.11.20128884 [dostęp: 13 X 2020].

Komunikat $n r$ 4. Ozonowanie jako metoda przeciwdziałająa skażeniu wirusem SARS-CoV-2, 27 III 2020 r., Centralny Instytut Ochrony Pracy - Państwowy Instytut Badawczy, https:// www.ciop.pl/CIOPPortalWAR/file/89653/2020033104228\&Komunikat-4-StanowiskoNC-ozonowanie.pdf [dostęp: 5 VIII 2020].

Opinia NIZP-PZH z dn. 2.04.2020 r. dot. dezynfekcji pomieszczeń biurowych poprzez ozonowanie i skuteczności powyższej metody w zwalczaniu SARS-CoV-2 oraz kwestii zwiazanych $z$ bezpieczeństwem jej stosowania, http://wsse.waw.pl/aktualnosci-i-komunikaty/komunikaty/ opinia-nizp-pzh-z-dn-2-04-2020-r-dot-dezynfekcji-pomieszczen-biurowych-poprzezozonowanie-i-skutecznosci-powyzszej-metody-w-zwal [dostęp: 5 VIII 2020].

Riddell S. $\mathrm{i}$ in., The effect of temperature on persistence of SARS-CoV-2 on common surfaces, „Virology Journal” 2020, nr 17, https://doi.org/10.1186/s12985-020-01418-7 [dostęp: 13 X 2020].

Szaflik J., Ozon - wróg czy przyjaciel?, „Biuletyn Informacyjny Stowarzyszenia nRetina AMD Polska”, http://idn.org.pl/psrp/ozon.html [dostęp: 20 VII 2020].

\begin{abstract}
Abstrakt
W artykule przedstawiono wyniki badań, których celem było określenie, w jakim stopniu ozon wykorzystywany do dezynfekcji pomieszczeń wpływa na możliwość ujawnienia metodą DFO śladów linii papilarnych na podłożach papierowych. Gwałtowny wzrost zachorowań na COVID-19 skierował uwagę na dezynfekcję pomieszczeń technikami, które zapewniają bezpieczeństwo ich użytkownikom. Istotne staje się także zapewnienie bezpieczeństwa osobom otrzymującym przesyłki, na których mogą się znajdować patogeny. Ich inaktywacja powinna być dokonana w taki sposób, aby można było przeprowadzić badania pozwalające na identyfikację nadawcy, co jest istotne z punktu
\end{abstract}


widzenia kryminalistyki. Ozonowanie jest techniką dezynfekcji wykorzystywaną od wielu lat, szczególnie do uzdatniania wody, w przemyśle spożywczym. Eksperymenty wykonano w pomieszczeniach o kubaturze ok. $20 \mathrm{~m}^{3}$ przy urzyciu generatora ozonu dostępnego na rynku. Uzyskiwane stężenie gazowego ozonu nie przekraczało 10 ppm. Przeprowadzone badania potwierdziły, że ślady linii papilarnych pozostawione na papierze kserograficznym umieszczonym w pomieszczeniu poddanym ozonowaniu w stężeniu nieprzekraczającym 10 ppm nie ulegają zniszczeniu i z powodzeniem mogą być ujawnione metodą DFO.

Słowa kluczowe: ślady linii papilarnych, daktyloskopia, DFO, ozon, papier, dezynfekcja, kryminalistyka.

\title{
The effect of ozone disinfection of rooms on the efficacy of revealing dactyloscopic traces on the surface of the paper using the DFO method during the SARS-CoV-2 pandemic
}

\begin{abstract}
The article presents the results of research aimed at determining the extent to which ozone used for disinfecting rooms affects the possibility of developing fingerprints on paper using the DFO method. A sudden increase in COVID-19 cases has placed the focus on disinfection techniques for user safety. It is also becoming important to ensure the safety of parcels addressed to various recipients by inactivating pathogens, while maintaining the possibility of examination that can identify the sender, which is important from the point of view of forensics. Ozonation is a disinfection technique that has been used for many years, in particular for water treatment or in the food industry. The experiments were carried out in rooms with a cubature of approx. $20 \mathrm{~m} 3$ using an ozone generator available on the market. The obtained ozone gas concentration did not exceed $10 \mathrm{ppm}$. The conducted research confirmed that the traces of fingerprints left on xerographic paper placed in a room subjected to ozonation in a concentration not exceeding $10 \mathrm{ppm}$ are not damaged and can be successfully developed with the DFO method.
\end{abstract}

Keywords: fingerprints, dactyloscopy, DFO, ozone, paper, disinfection, forensics. 